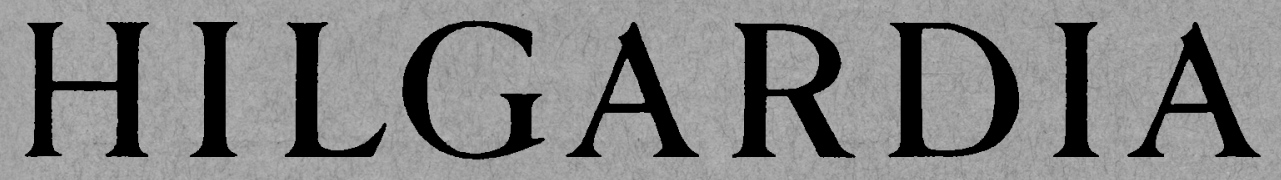

A Journal of Agricultural Science Published by the California Agricultural Experiment Station

\title{
SOME ANATOMIC ASPECTS OF THE STRAWBERRY ROOT
}

\author{
PAUL E. NELSON \\ and \\ STEPHEN WILHELM
}

UNIVERSITY OF CALIFORNIA • BERKELEY, CALIFORNIA 
The continued production of new adventitious roots from the crown and the ability of these roots to establish themselves as perennial by producing secondary tissues are basic to healthy strawberry-plant growth. This main root structure in turn produces successive crops of lateral absorptive rootlets, which make up the transient portion of the root system. The anatomical studies of strawherry roots described in this paper indicate that the extent to which these processes take place unimpeded largely determines the health and vigor of the plant. 


\section{H I L G A R D I A}

A Journal of Agricultural Science Published by

the California Agricultural Experiment Station

\section{SOME ANATOMIC ASPECTS OF THE STRAWBERRY ROOT}

\section{PAUL E. NELSON ${ }^{2}$ and STEPHEN WILHELM ${ }^{3}$}

THE RоOT GROWTH and development of the healthy strawberry has been studied with special emphasis on the anatomy of both the main adventitious roots and the small feeder rootlets. This paper presents the results of these studies; a preliminary report has already appeared (Nelson and Wilhelm, 1952)..$^{4}$

\section{MATERIALS AND METHODS}

The studies reported herein were conducted mainly on the Lassen and Shasta varieties of the garden strawberry (Fragaria virginiana $\times F$. chiloensis). The plants were grown either in chloropicrin-fumigated field soil in the general area of Watsonville, California, or in 12-inch pots of fumigated potting soil in a greenhouse at the University of California, Berkeley, California.

The root material used in preparing the permanent slides and the photomicrographs was killed in Rawlins' alcohol-formalin-acetic acid fixing solution No. 1 (Rawlins, 1933). After dehydration according to the normal butyl alcohol schedule (Rawlins, 1933), the material was imbedded in paraffin. Sections 10 microns thick were cut on a rotary microtome and stained with a modified Johansen's quadruple stain (Johansen, 1940). Tests for suberin were made according to the method given by Rawlins and Takahashi (1952).

\section{ROOT DEVELOPMENT IN FIELD-GROWN PLANTS}

Various authors have studied the growth and root distribution in soil of various strawberry varieties (Ball and Mann, 1927; Goff, 1897; Hanson, 1931; Mann and Ball, 1926, 1927; Weaver and Bruner, 1927). Weaver and Bruner (1927), in studies with the Dunlap variety, reported that the fibrous root system of the strawberry arises from the short, thick stem near the soil surface. Just beneath the soil surface horizontal roots extend about 1 foot on all sides of the base of the plant. The root system was found to be rela-

${ }^{1}$ Submitted for publication September 18, 1956.

2 Formerly Research Assistant in Plant Pathology, University of California, Berkeley; now Assistant Professor of Plant Pathology, Cornell University, Ornamentals Research Laboratory, Farmingdale, New York.

${ }^{3}$ Associate Professor of Plant Pathology and Associate Plant Pathologist in the Experiment Station, Berkeley.

"See "Literature Cited" for citations, referred to in the text by author and date. 
tively shallow, with the most profuse root branching occurring in the upper 12 inches of soil. Hanson (1931), studying the root and top development of 18 strawberry varieties, reported that under the conditions of his experiment the root systems of plants were usually shallow. The maximum depth of roots varied from $101 / 2$ inches in the Aroma variety to 40 inches in the Mastodon variety, while the maximum lateral spread from the crown varied from 12 to 40 inches. Ball and Mann (1927), in a series of studies on root and shoot development of strawberry, reported that with 2-year-old plants 90 per cent of the total root system was in the uppermost 6 inches of the soil.

In the first year after striking a runner, under California conditions, a healthy strawberry plant produces a large number of adventitious roots from the crown. From these, branch roots arise. Branching may continue through four or five divisions, ending in numerous fine rootlets. In light, sandy soils around Watsonville, California, the root system extends to a depth of about 2 feet with extensive branching to that depth.

The main adventitious roots of healthy strawberry plants are perennial and produce secondary tissues. The perennial main root system is also augmented by the formation of new adventitious roots as the crown growth increases.

\section{ANATOMY OF THE MAIN ADVENTITIOUS ROOTS}

In the spring a newly formed adventitious root is white to light brown. As the season progresses, the color gradually darkens until in the fall and winter months it becomes dark brown to black. At first glance one might think that these dark-colored roots are either diseased or dead. Mann and Ball (1927), working with field-grown strawberry plants, reported that after two years none of the primary or main roots had died, and that the roots formed in the autumn after spring planting were thick and quite black. However, when this black and dead outer tissue was scraped away, a white living core could be seen. Similar conditions occur in field-grown plants in California, and these color changes may merely reflect anatomic changes taking place in the root. An awareness of this phenomenon is essential to those studying strawberry roots, especially to plant pathologists, since this color change may be mistakenly considered to be a symptom of disease.

Adventitious roots arising in the spring remain in the primary state until the following fall or early winter (plate 1). The first indication of the development of secondary tissues is the appearance of vascular cambial strands between the points of the usually tetrarch xylem tissues of the root (plate 2). Lateral extension of the vascular cambial strands continues until the complete cambial ring is formed (plate 3 ). In the main adventitious roots, the development of vascular cambium always precedes the formation of the cork cambium. After considerable secondary phloem and xylem have been formed, a cork cambium becomes active. The first evidence of cork cambial activity is an increase in the number of cell layers in the region of the pericycle immediately beneath the endodermis, and shortly thereafter scattered cells in one of the layers of this tissue become suberized (plate 3 ). Eventually an entire layer of cells in this area may become suberized. The presence of suberin was determined by the use of Sudan IV (Rawlins and 
Takahashi, 1952) on paraffin sections prepared as described earlier in this paper. This cork cambium gives rise to the tissue known as the polyderm (Mann, 1930; Mylius, 1913). The polyderm continues to expand by the addition of new cell layers (plate 4), and this expansion along with the activity of the vascular cambium causes sloughing of the cortical tissues. Plate 4 shows a transection of a root in which the cortex has been entirely replaced by polyderm. The polyderm is composed of alternating layers of suberized and unsuberized cells and may reach a thickness of 20 or more cell layers. Typically, two to four cell layers of unsuberized cells alternate with a single layer of suberized cells. The outermost portion of the polyderm is composed of suberized dead cells which no doubt act as protective tissue. During the fall and winter months the unsuberized cell layers of the polyderm contain large quantities of starch and function as storage tissue.

The pattern of development for secondary phloem and xylem tissues in the strawberry root is the same as that typical of the roots of dicotyledons. Secondary xylem develops centripetally, and secondary phloem centrifugally, from the vascular cambium. Strawberry roots have a comparatively small amount of phloem tissue in proportion to the amount of xylem and size of the root (plate 4). In comparison with the woody root of the pear, as described by Esau (1943), the amount of phloem in a strawberry root is small indeed.

\section{ANATOMY OF THE FINE LATERAL ROOTS}

While the main adventitious roots and their principal branches are perennial, the fine lateral roots, which make up a large portion of the total root system, are only transient. In our studies of strawberries grown into the second year in pots and in the field under as nearly ideal growing conditions as could be provided, we found that the fine lateral rootlets died; they died on plants that had a well-developed perennial root system. Mann and Ball (1927) reported essentially this same phenomenon. Jones (1943), in studies on roots of alfalfa, described two types of roots, permanent cambial and transient noncambial. The permanent roots consisted almost entirely of secondary tissues, whereas the transient rootlets developed little or no secondary tissues.

Anatomically the small lateral noncambial rootlets of the strawberry are composed almost entirely of primary tissues (plate 5). Occasionally rootlets can be found that have begun to form polyderm tissue without any vascular cambial activity having taken place (plate 6). The reasons for polyderm development in these roots are not known, but the effect of unfavorable environment, such as drought, or of attack by fungi may be involved.

An additional characteristic of the healthy strawberry plant is the ability of the root system to produce new successive crops of the small lateral rootlets from old perennial roots (plate 7). Not only does the old perennial root system function in the storage of food materials, but by continuing to grow in length and by producing crops of new feeder roots, it contributes directly to an active absorptive function.

In main adventitious roots still composed entirely of primary tissues, the small lateral roots are initiated in the pericycle opposite the xylem ridges. However, the authors have been unable to determine the exact point of initia- 
tion of these lateral feeder rootlets from old adventitious roots consisting chiefly of secondary tissues. It is believed that they may arise from the cork cambial initials themselves or from the immediately adjacent derivatives of these initials. Priestley and Swingle (1929) found buds arising from a meristematic layer lying internal to a polyderm in roots of Rubus idaeus.

\section{DISCUSSION AND SUMMARY}

In certain light sandy soils in California, the root system of a strawberry plant extends to a depth of about 2 feet, with extensive branching to that depth. The main adventitious roots of healthy strawberry plants and their prominent branches are perennial and develop extensive secondary tissues from vascular and cork cambiums. These roots form the basic pattern for the perennial root system and contribute to the perennial nature of the plant. Under ideal conditions, it is conceivable that this root system could live almost indefinitely. These large roots function as storage organs and also contribute directly to the active absorptive function of the root system by continuing to grow in length and by producing successive crops of new lateral rootlets. The lateral rootlets produced by the main adventitious roots and their prominent branches generally do not produce secondary growth and appear to be transient.

Anatomically the large adventitious roots exhibit a unique tissue known as the polyderm (Mann, 1930; Mylius, 1913). The polyderm is composed of alternating bands of suberized and unsuberized cells. Usually two to four cell layers of unsuberized cells alternate with a single layer of suberized cells. This tissue is initiated by the cork cambium in the pericycle region of the adventitious roots and has both a protective and storage function.

The health of a strawberry plant as far as root growth is concerned, then, is dependent on the continued production of new adventitious roots from the crown and on the ability of these roots to produce secondary tissues which insure their perennial existence. This main root structure, which forms the permanent portion of the root system, in turn produces successive crops of lateral absorptive rootlets. These rootlets make up the transient portion of the root system. It is believed that the extent to which these processes take place unimpeded largely determines the health and vigor of the plant. 


\section{LITERATURE CITED}

BaLl, E., and C. E. T. MANN

1927. Studies in the root and shoot development of the strawberry. IV. The influence of some cultural practices on the normal development of the strawberry plant. Jour. Pomol. and Hort. Sci. 6:104-112.

Esau, Katherine

1943. Vascular differentiation in the pear root. Hilgardia $15: 299-324$.

GoFF, E. S.

1897. The roots of the strawberry plant. Trans. Wisconsin State Hort. Soc. $27: 248-256$.

Hanson, Herbert C.

1931. Comparison of root and top development in varieties of strawberry. Amer. Jour. Bot. 18:658-673.

JoHANSEN, D. A.

1940. Plant microtechnique. 523 pp. McGraw-Hill Book Company, Inc., New York.

JoNES, F. R.

1943. Growth and decay of the transient (noneambial) roots of alfalfa. Jour. Amer. Soc. Agronomy 35:625-634.

MANN, C. E. T.

1930. Studies in the root and shoot growth of the strawberry. V. The origin, development, and function of the roots of the cultivated strawberry (Fragaria virginiana $\times$ F. chiloensis $)$. Ann. Bot. 44:55-86.

MANN, C. E. T., and E. BALL

1926. Studies in the root and shoot growth of the strawberry. Jour. Pomol. and Hort. Sci. 5:149-169.

MANN, C. E. T., and E. BALL

1927. Studies in the root and shoot development of the strawberry. Jour. Pomol. and Hort. Sci. 6:81-112.

Mylius, G.

1913. Das Polyderm. Eine vergleichende Untersuchung über die physiologischen Scheiden Polyderm, Periderm und Endodermis. Biblioth. Bot. Heft 79, 119 pp.

NELSON, P. E., and S. WILHELM

1952. Strawberry root anatomy with special reference to black root rot. (Abst.) Phytopathology 42:517.

Priestley, J. H., and C. F. Swingle

1929. Vegetative propagation from the standpoint of plant anatomy. U. S. Dept. Agr. Tech. Bul. 151.

Rawlins, T. E.

1933. Phytopathological and botanical research methods. $156 \mathrm{pp.} \mathrm{John} \mathrm{Wiley} \mathrm{and} \mathrm{Sons,}$ Inc., New York.

RaWLins, T. E., and W. N. Takahashi

1952. Technics of plant histochemistry and virology. 125 pp. The National Press, Millbrae, California.

WeAver, J. E., and W. E. Bruner

1927. Root development of vegetable crops. 351 pp. MeGraw-Hill Book Company, Inc., New York. 


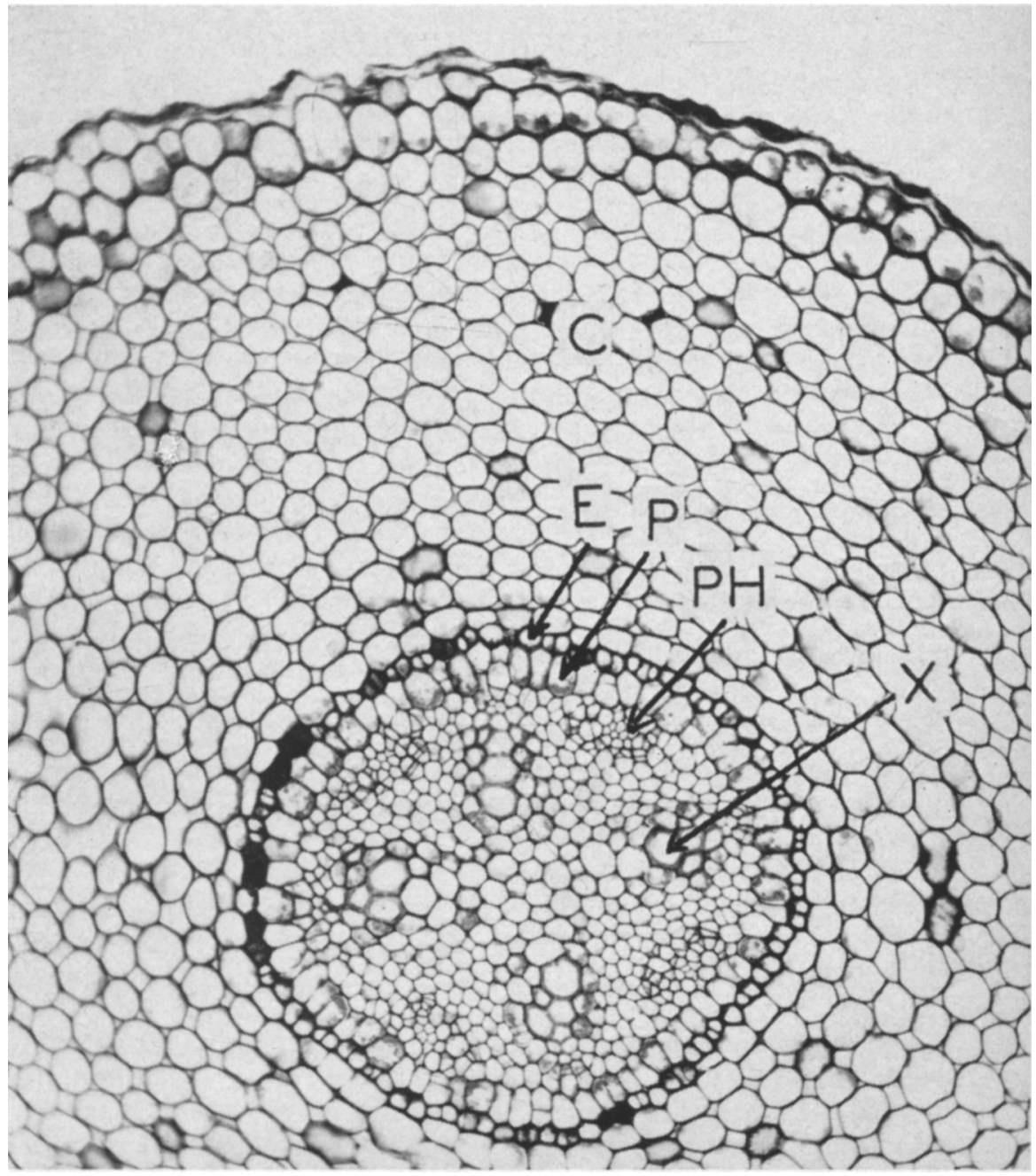

Fig. 1. Transection of a main adventitious root of strawberry showing the primary tissues derived from the apical meristem. C, cortex; E, endodermis; P, pericycle; PH, phloem; X, xylem. $(\times 225$. 


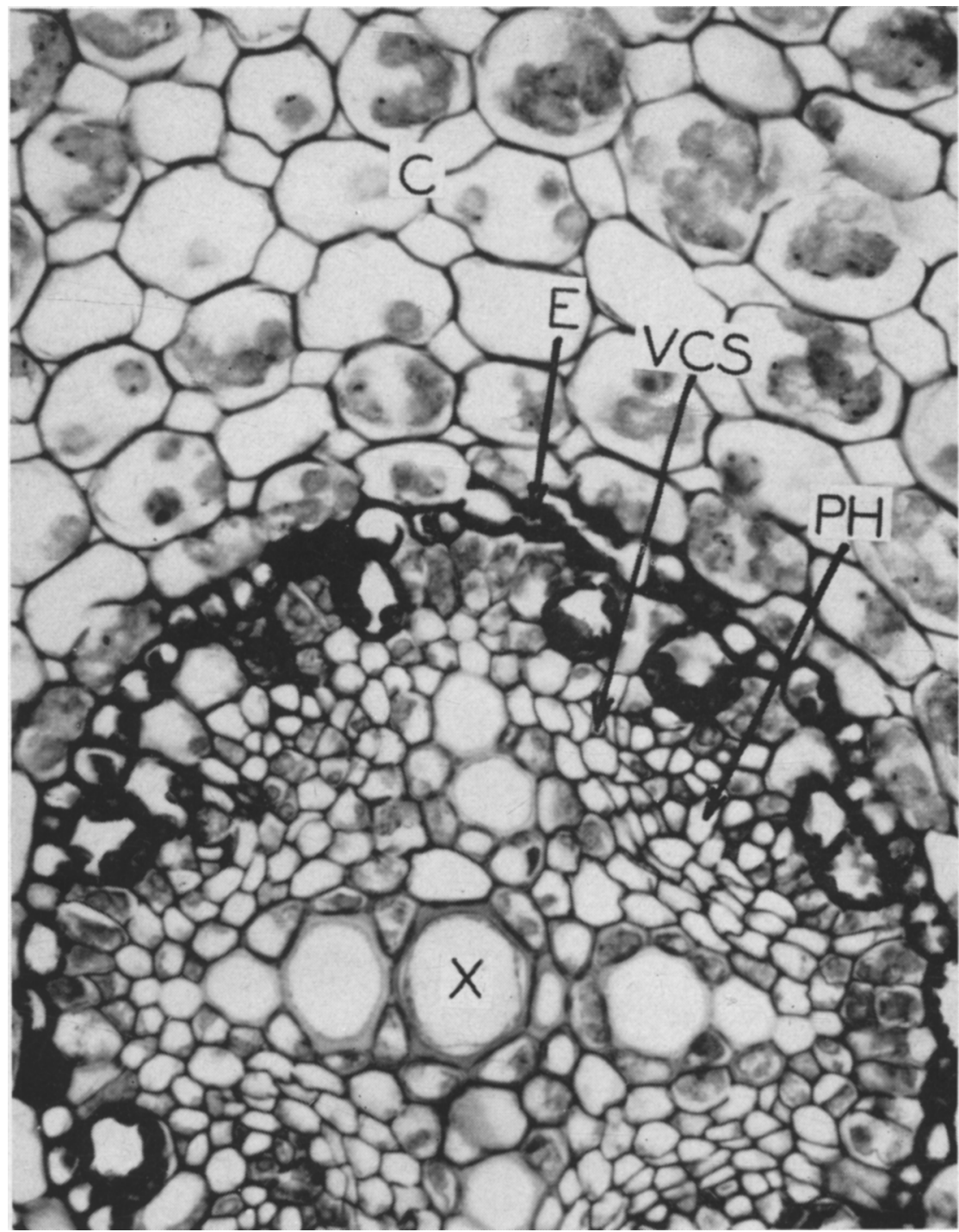

Fig. 2. Transection of a main adventitious root of strawberry showing the vascular cambial strands-VCS-between the xylem poles. $\mathrm{X}$, xylem vessel element; $\mathrm{PH}$, phloem; E, endodermis ; C, cortex. ( $\times 205$. $)$ 


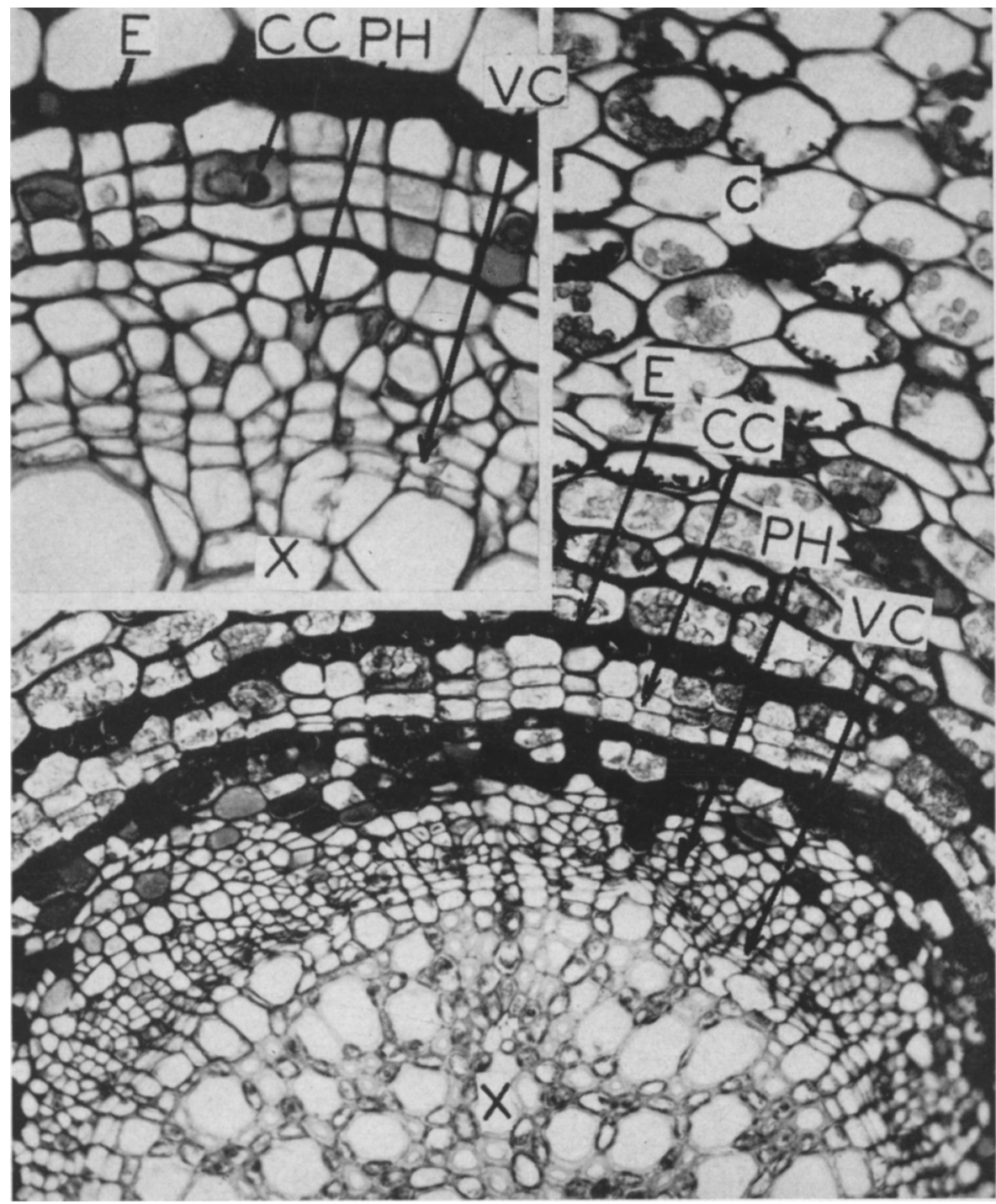

Fig. 3. Transections of two main adventitious roots of strawberry showing a welldeveloped vascular cambium and early cork cambial activity. $\mathrm{X}$, xylem; VC, vascular cambium ; PH, phloem; CC, cork cambium; E, endodermis; C, cortex. The inset $\times 675$ shows the initiation of the cork cambium, immediately beneath the endodermis. The bands of deeply stained cells contain suberin. $(\times 285$. $)$ 


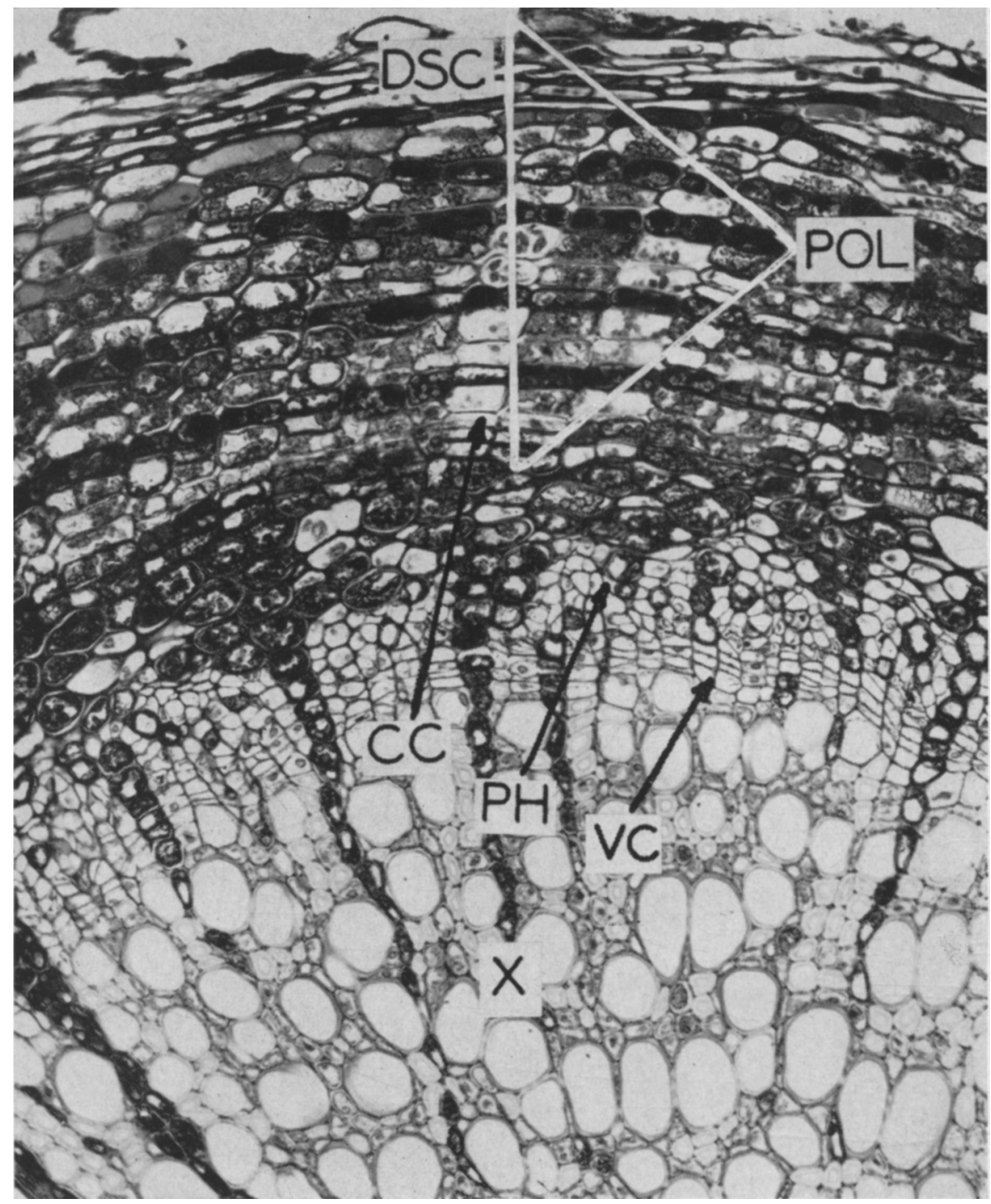

Fig. 4. Transection of a two-year-old main root of strawberry showing well-developed secondary tissues. POL, polyderm; note the alternating layers of deeply stained and lightly stained cells. The deeply stained cell layers contain suberin. PH, phloem; VC, vascular cambium; $X$, xylem; DSC, dead suberized cells forming an outer protective tissue. $(\times 248$. 


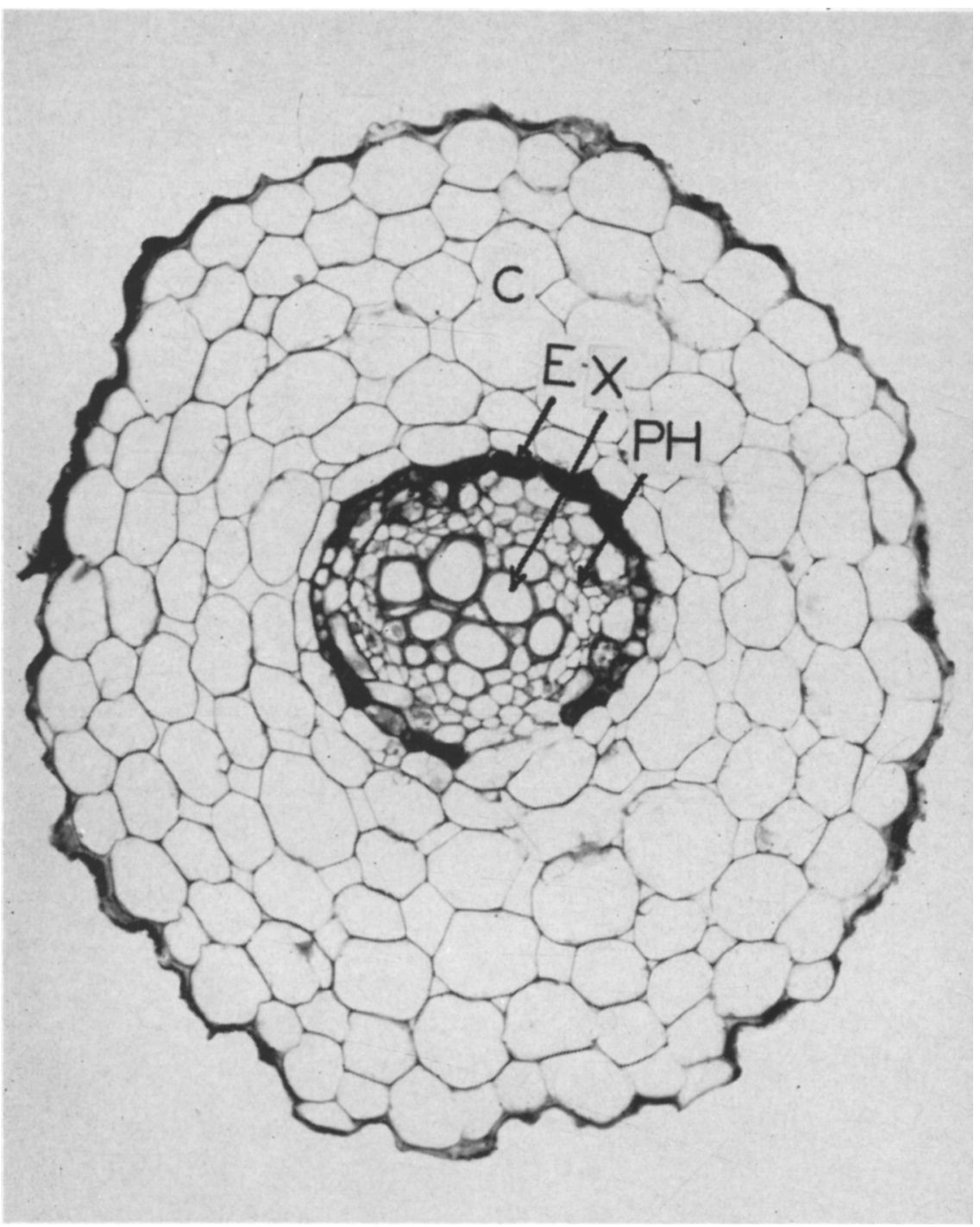

Fig. 5. Transection of a feeder rootlet of strawberry. These characteristically are composed of primary tissues only. C, cortex; E, endodermis; $\mathrm{PH}$, phloem; X, xylem. $(\times 375$. 


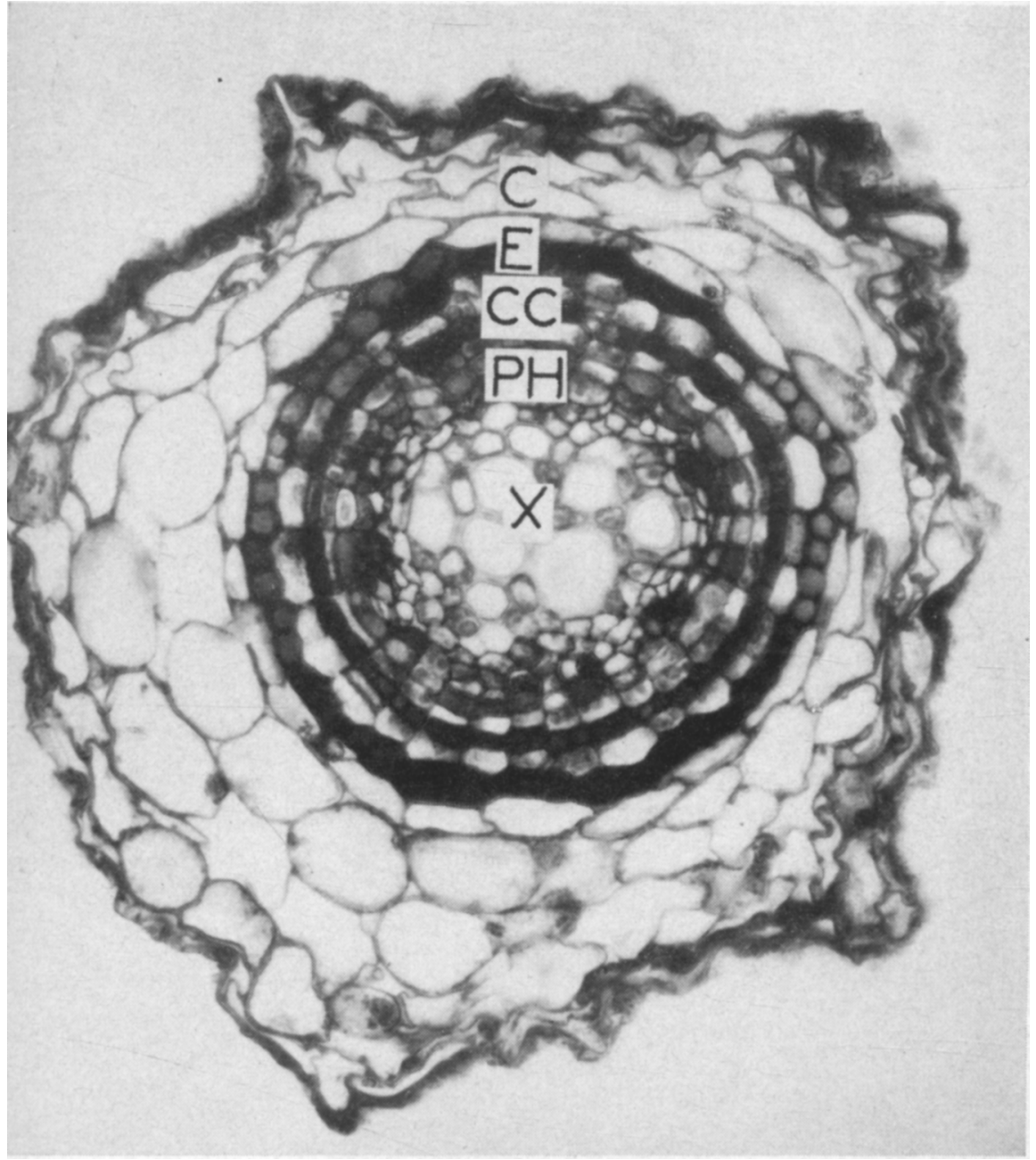

Fig. 6. Transection of a feeder rootlet of strawberry showing cork cambial activity. C, cortex; E, endodermis: CC. cork cambium; PH, phloem; X, xylem. $(x 460.2$ 


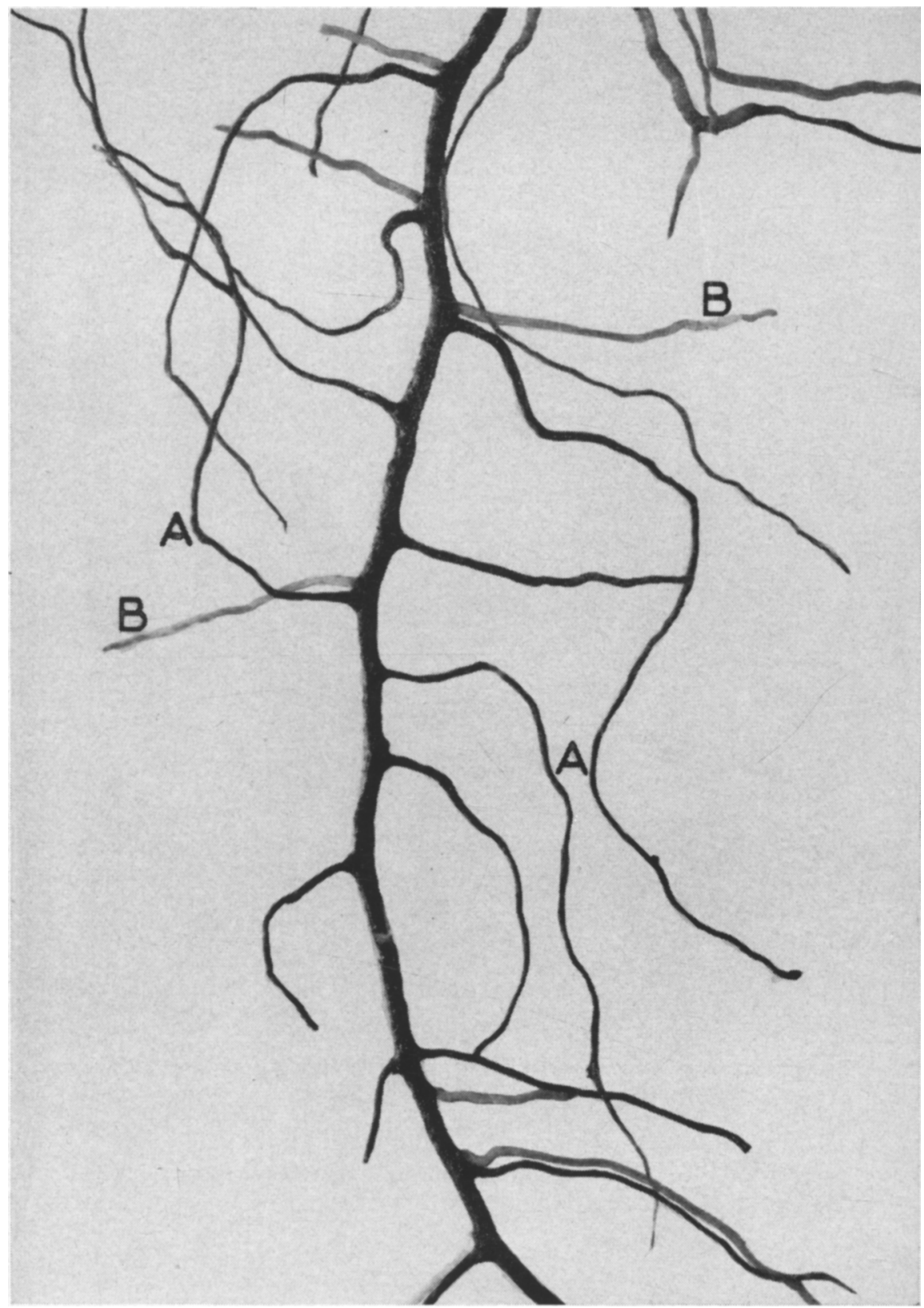

Fig. 7. Portion of a main adventitious root from a 3-year-old strawberry root showing dead (A) and living (B) feeder rootlets. Feeder rootlets are noncambial, transient, and produced in successive crops. 
The journal Hilgardia is published at irregular intervals, in volumes of about 600 pages. The number of issues per volume varies. Subscriptions are not sold. The periodical is sent as published only to libraries, or to institutions in foreign countries having publications to offer in exchange.

You may obtain a single copy of any issue free, as long as the supply lasts; please request by volume and issue number from:

\section{Agricultural Publications \\ Room 22, Giannini Hall \\ University of California \\ Berkeley 4 , California}

The limit to nonresidents of California is 10 separate issues on a single order. A list of the issues still available will be sent on request. 